\title{
INVESTIGATION OF SEAPORT AIR DUSTINESS AND DUST SPREAD
}

\author{
Pranas Baltrẻnas, Klaus-Diter Fröhner, Mantas Pranskevičius \\ Dept of Environmental Protection, Vilnius Gediminas Technical University, \\ Sauletekio al.11,LT-10223 Vilnius, Lithuania.E-mail:Rambaldi@delfi.lt \\ Submitted 14 Apr 2006; accepted 11 Nov 2006
}

\begin{abstract}
In the present study investigation of dustiness, performed at Public Limited Liability Company KLASCO, the Company of State Seaport of Klaipeda is described. During investigation the sources of dust formation and the main reasons, impacting the concentration of dust were analysed. Tests were performed at 12 points, located in two zones in the territory of the enterprise. Tests were also performed at the Terminal of Powdery Manure Discharge. Concentrations of dust of manure of potassium chloride during loading were measured. In order to evaluate impact of the enterprise, the data of measurements made at the same time in the northern part of Klaipeda city were used. The obtained data were demonstrated by Surfer 6 software. According to the isolines, analysis of dust spread was performed.
\end{abstract}

Keywords: optical method, mass method, Terminal of Powdery Manure Disharge, air dustiness, dust spread, simulation.

\section{Introduction}

Klaipeda is a seaport city where there are more than 60 big industrial enterprises which are established on the coast of the Curonian Lagoon and the Baltic Sea. This port is famous as an ice-free port. Therefore, lots of sea freights pass this port.

$\mathrm{AB}$ Klasco is a state enterprise of the seaport, involved in reloading, storage and transportation of such freights. In this enterprise, materials like grain, sugar, powdery manure, ferroalloy, etc are reloaded. During performance of various reloading, transporting and processing works in the territory of the enterprise, dust, contaminating the environment, is usually formed. Scentless dust is hazardous not only for the workers of the enterprise, but also for people round about because part of dust falls over the limits of the enterprise to a habitable territory [1].

The main sources of dust emission in the territory of the enterprise are works of loading and transportation of powdery materials as well as terminals of discharge of grain and powdery manure. Although at the terminal of grain discharge, dust is formed during grain discharge, however, the distance and warehouses of powdery manure of 30 metres height have a great impact on their spread. Meanwhile, manure dust, formed at the Terminal of Powdery Manure Discharge, is a matter of greater concern. The Terminal is only at a distance of 47 metres from a habitable territory. The only obstacle holding dust is a silencing wall of 8 metres height.

The most hazardous for the habitable territory, according to prevailing wind direction, are directions of South-West and West because at the wind of such a direction, dust forming in the territory is carried to the habi- table territory from the territory of the enterprise. According to meteorological data, annual repeatability of the South-West wind is 17 . The rate of repeatability of the West wind is 16 .

The impact of formed dust on the environment will depend on the density, abrasivity, powderity, adhesion, form and dispersity of dust. According to dispersity, dust is classified into 5 classes. The most hazardous of them are hard particles of the 5-th class. These hard particles are not stopped by human upper airway; therefore, they may lay low with airway diseases. Depositing on mucous membrane of nose, trachea, bronchi, they arouse inflammatory reactions, eventually they develop chronic hypertrophic and atrophic catarrhs. Later people get sick with such airway diseases as bronchitis, tracheitis, pneumonia, (diffusive sclerosis of the lungs). Loading ferroalloy, stirred up metal impacts development of side-erosion.

Dust is very irritating. In the case of contact with eyes, dust irritates mucous membrane of eyes and eventually develops conjuctivitis, blefaritis, ceratoconjuctivitis, which are evidenced by eye redness, running eyes. Sometimes eyes even become rheumy. If swallowed, dust causes diseases of the digestive system, and toxic dust intoxication.

In the case of contact with skin, dust blocks pores of sweat-gland and oil-gland. Skin becomes spotted, and bacteria on the surface of the skin may impact development of gatherings [2].

For measurements at Klaipèda Seaport, devices based on mass and optical methods of operation were selected. First of all measurements were made using the mass method which was applied as a control method for the optical one. Whereas, devices, operating by the optical method, measure not only hard particles but also aerosols. 
Comparing precision, the bias of mass gauge was $25 \%$, therefore for measurements, a more precise optical method was used.

Measurements were started in August and finished in November. Measurements were made every month.

The objective of the present study is to determine the level of air pollution by dust in the territory of Klaipeda Seaport as well as in the habitable territory near the Port.

Also, it was endeavoured to evaluate the level of dustiness inside the Terminal of Powdery Manure Discharge and at a distance of 50 metres from the gates of the Terminal. The obtained data were demonstrated by Surfer 6 software.

\section{Investigation methodology}

Investigation of dustiness was performed using the mass and optical methods. Dustiness was measured applying the mass method, using an electrical aspirator with bias of suction rate $\pm 6 \%$. During measurement dust was stopped on a filter after sucking through it 6001 of air volume. For sampling, filters AFA-VP-20 were used. Air sample was taken at a height of $1,5 \mathrm{~m}$ from the ground surface. The rate of suction was $20 \mathrm{l} / \mathrm{min}$, the time of suction was $30 \mathrm{~min}$. Later the mass of dust was detected by weighting. During weighting of the filters the following conditions were kept [3]:

- air temperature was $(20 \pm 10){ }^{\circ} \mathrm{C}$,

- atmospheric pressure was $(84,0-106,7) \mathrm{kPa}$ or (630800) $\mathrm{mm} \mathrm{Hg}$ of the column,

- air humidity, at a temperature of $25^{\circ} \mathrm{C}$ was not higher than $80 \%$.

Measurements, using the mass method, were made following the requirements of the normative document LAND 26-98/M-06. Measurements, applying the optical method, were made by the air gauge Microdust Pro. Measurements by this gauge were made in four diapasons $[4,5]$ :

- from 0,001 to $2,5 \mathrm{mg} / \mathrm{m}^{3}$, bias of measurement $0,001 \mathrm{mg} / \mathrm{m}^{3}$;

- from 0,01 to $25,0 \mathrm{mg} / \mathrm{m}^{3}$, bias of measurement $0,01 \mathrm{mg} / \mathrm{m}^{3}$

- from 0,1 to $250,0 \mathrm{mg} / \mathrm{m}^{3}$, bias of measurement $0,1 \mathrm{mg} / \mathrm{m}^{3}$;

- from 1,0 to $2500 \mathrm{mg} / \mathrm{m}^{3}$, bias of measurement $1,0 \mathrm{mg} / \mathrm{m}^{3}$.

The gauge uses modulated IR (infrared radiation), spreading into a chamber of measurement.

At clean-air conditions the entire light is kept in a collector of light. When dust particles enter receptacle of a sample, the rays of light are spread by a narrow angle $\left(12-20^{\circ}\right)$ to the collector. The intensity of diffused light is measured by a detector of infrared rays. Measured value is converted into dust concentration.

Measurements by this gauge were made at a height of 1,5 metres from the ground surface. Duration of measurement was 5 minutes.

In the enterprise tests of dustiness were performed at 12 points, located in the territory (Fig 1). Air dustiness was tested in the day time ( $6 \mathrm{a} \mathrm{m-6} \mathrm{p} \mathrm{m)} \mathrm{and} \mathrm{in} \mathrm{the} \mathrm{eve-}$ ning $(6 \mathrm{p} \mathrm{m}-10 \mathrm{p} \mathrm{m})$ applying the mass and optical me- thods. The mass method was used as a controlling method to the optical one.

Location of measuring points was selected in such a way that it could be the most representative of dust pollution in the territory of the enterprise. The measuring were divided into two zones each with six measuring points (zone I had points 1-6, zone II - points $1-12$ ).

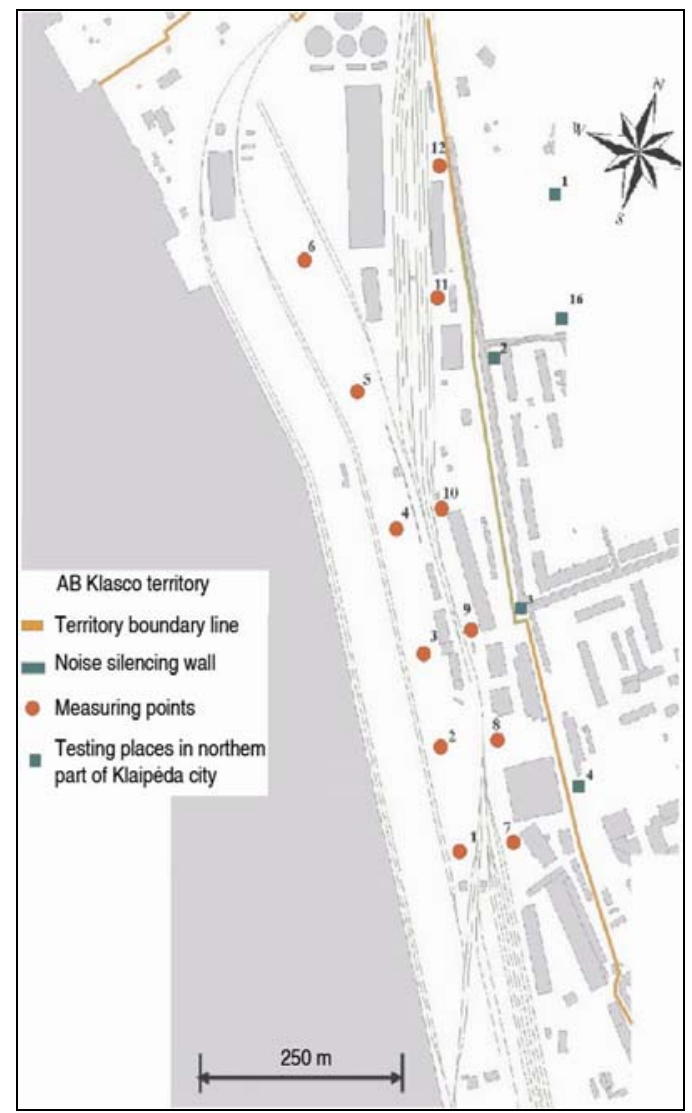

Fig 1. Points of measuring air dustiness in the territory of Klaipèda Seaport

Zone I is located along the quay where dust pollution is mostly caused by the works of loading at ships and wagons. The measuring points in this zone are located at a distance of 80 metres from the quay every 100 metres. At points $1-4$, the main works of loading from ships and loading or discharging of wagons are performed. Points 6 and 5 were selected near the loading line of ships. Zone II is located in the territory of the enterprise in parallel with zone I. The target of testing of this zone is to detect other sources of dustiness, to evaluate their impact on the environment and to evaluate the carry from zone I and the carry outside the territory of the enterprise. Measuring points 11 and 12 were chosen to test the impact of the Terminal of Powdery Manure Discharge on the air dustiness.

Tests of dustiness were also performed at the Terminal. Measuring points were located in order to get more information about the distribution of dustiness inside the Terminal and at a distance of 50 metres from the gate of the Terminal (Fig 2). The points were located in the middle of each loaded wagon from both sides. Also, measurements were made above wagons in order to evaluate 
spatial distribution of dustiness. Measuring points were divided into zones. Zone I had points $2-6$, zone II -18 20 , zone III $-15-17$, zone IV - 9-13. Measuring points above wagons were attributed to both zones between which they were located. Measuring points 1, 2, 8, 7 and 14 were selected to evaluate the environmental air pollution. They were located in front of or behind the Terminal.

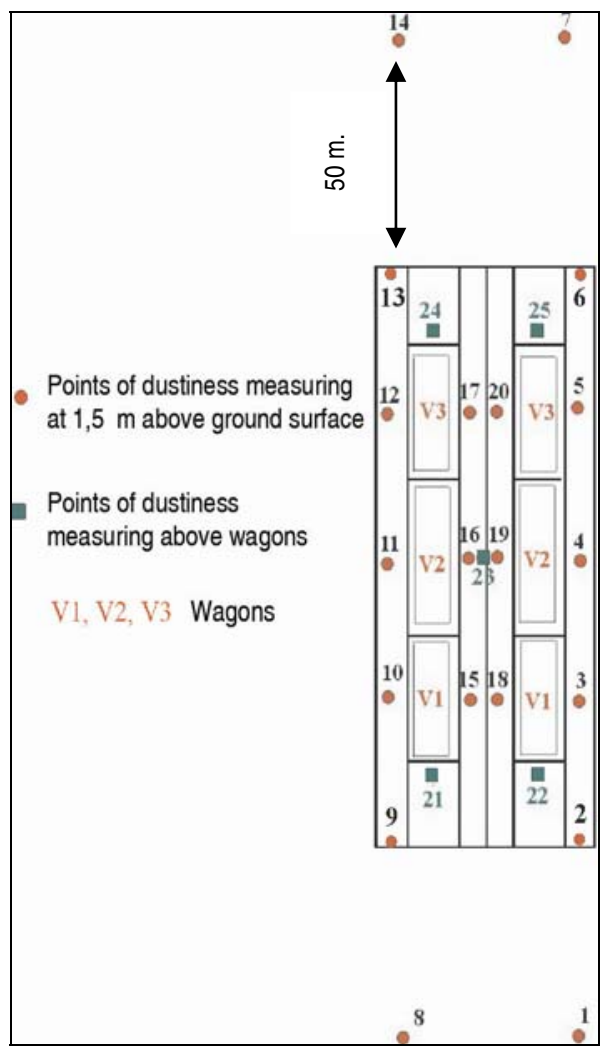

Fig 2. Points of measuring dustiness at Terminal of Powdery Manure Discharge

\section{Investigation results}

Analysing the collected data, it was determined that on August 23 and 25 the highest concentrations in the daytime were detected in the busiest zone at the warehouses of ferroalloy, measuring points 8 and 9 , and on the quay at measuring points 2 and 6 (Fig 3). Interim isolines of exceeded concentrations extended along the quay about $80 \mathrm{~m}$, and in the territory of the enterprise about $250 \mathrm{~m}$ near the warehouses of ferroalloy. The biggest source of pollution was at the warehouses of ferroalloy due to heavy traffic and works of storage of ferroalloy at measuring point 9 . The detected concentration exceeded the highest allowable concentration (HAC) 1,9 time. Exceeded concentrations were also detected at measuring point 8 . It was detected that HAC was exceeded 1,18 time. Air pollution at this measuring point was also caused by traffic and air carry from the quay.

During measuring the wind was of prevailing western direction of $1 \mathrm{~m} / \mathrm{s}$, relative humidity was $49,3 \%$, air temperature was $24,9^{\circ} \mathrm{C}$.

On the quay measuring points 2 and 3 were located in the zone of the most intensive loading. At the other points on the quay, loading is performed rarer, whereas the biggest part of it is covered by metal products. Exception is only at measuring point 6 where loading is also performed, however, it is less intensive than at measuring points 2 and 3 . Therefore, on the quay, at measuring point 2 , due to intensive works of loading 1,34 time excess of HAC was detected. The level of air pollution at this measuring point was determined by loading of ferroalloy. Ferroalloy was loaded that day at measuring point 6 too. Excess of concentrations around this measuring point distributed at a distance of $30 \mathrm{~m}$. Dust concentration was exceeded 1,06 time. Around the Terminal of Powdery Manure Discharge, concentrations did not exceed HAC and decreased gradually coming nearer to a noise silencing wall. Decrease of concentrations in the living environment at the Terminal and at the noise silencing wall varied from $0,05 \mathrm{mg} / \mathrm{m}^{3}$ at houses on Švyturys street to $0,1 \mathrm{mg} / \mathrm{m}^{3}$ in their yards, in comparison with the concentrations detected in the territory of the enterprise.

No excess of concentrations was detected in the territory of the enterprise in the evening on August 25. The highest concentrations were in the zone of the most intensive loading (measuring points 2 and 3 ) and in the zone of the heaviest traffic (measuring points 8 and 9), and they varied from $0,44 \mathrm{mg} / \mathrm{m}^{3}$ to $0,30 \mathrm{mg} / \mathrm{m}^{3}$. These concentrations extended along the quay about 300 metres.

Decrease of concentrations at the Terminal of Powdery Manure Discharge and at the noise silencing wall was about $0,02 \mathrm{mg} / \mathrm{m}^{3}$ in front of houses on Švyturys street, and it was $0,04 \mathrm{mg} / \mathrm{m}^{3}$ in teir yards in comparison with the concentrations in the territory of the enterprise (Fig 4). Excess of concentrations was not detected because works of loading, performed on the quay, were not as intensive as in the daytime.

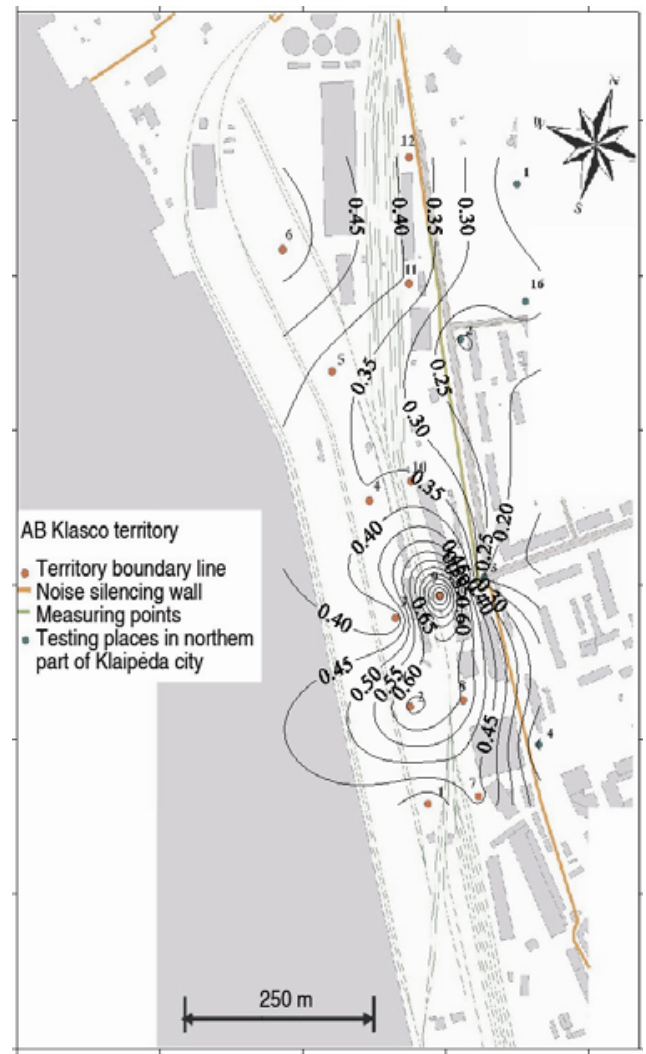

Fig 3. Dustiness in the daytime in August 
Decreased rate of the wind had an influence too. During measuring the West wind of $0,5 \mathrm{~m} / \mathrm{s}$ was blowing, increased relative humidity was $52,2 \%$, air temperature was $23,12^{\circ} \mathrm{C}$.

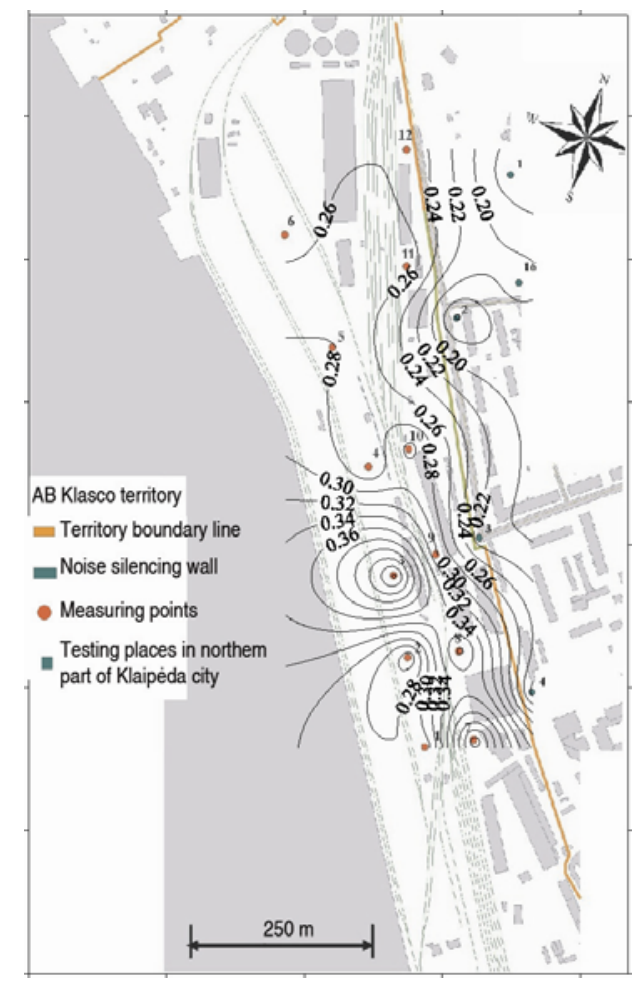

Fig 4. Dustiness in the evening in August

Comparing dust concentrations in zones I and II, we observe that in the daytime in zone I concentrations exceeded the ones in the evening 1,47 time, and in zone II concentrations in the daytime were 1,59 time higher than in the evening. In zone I concentrations in the daytime were 1,20 time less than in zone II. In the evening, in zone I concentrations were 1,11 time lower than in zone II.

In comparison with the daytime, in the evening concentrations in the territory of the enterprise spread in a bigger area and were lower. It was influenced by meteorological conditions.

In the daytime on September 20 the excess of dust concentrations spread between the main loading zone on the quay and the zone of heavy traffic (measuring points 2,3 and 8,9). Detected excess of HAC on the quay varied from 1,11 to 1,42 time. In the zone of heavy traffic HAC values varied from 0,11 to 1,09 time (Fig 5). During measuring, the West wind of $2 \mathrm{~m} / \mathrm{s}$ was blowing, relative humidity was $74 \%$, air temperature was $16,5^{\circ} \mathrm{C}$. Concentrations in this rectangle varied from 0,35 to $0,95 \mathrm{mg} / \mathrm{m}^{3}$. The main concentrations spread about $350 \mathrm{~m}$ along the quay. Lower concentrations were detected at the Terminal of Powdery Manure Discharge. They varied from $0,32 \mathrm{mg} / \mathrm{m}^{3}$ to $0,40 \mathrm{mg} / \mathrm{m}^{3}$. Formation of such concentrations was influenced by dust emitted by the Terminal during loading.

In the living environment concentrations downwind decreased by $16 \%$ due to the influence of the noise silen- cing wall on Pušynas street. On Švyturys street concentrations varied from $0,032 \mathrm{mg} / \mathrm{m}^{3}$ at the Terminal to $0,038 \mathrm{mg} / \mathrm{m}^{3}$ at the warehouses of ferroalloy. In the yards on Švyturys street dust concentrations varied from $0,030 \mathrm{mg} / \mathrm{m}^{3}$ to $0,034 \mathrm{mg} / \mathrm{m}^{3}$.

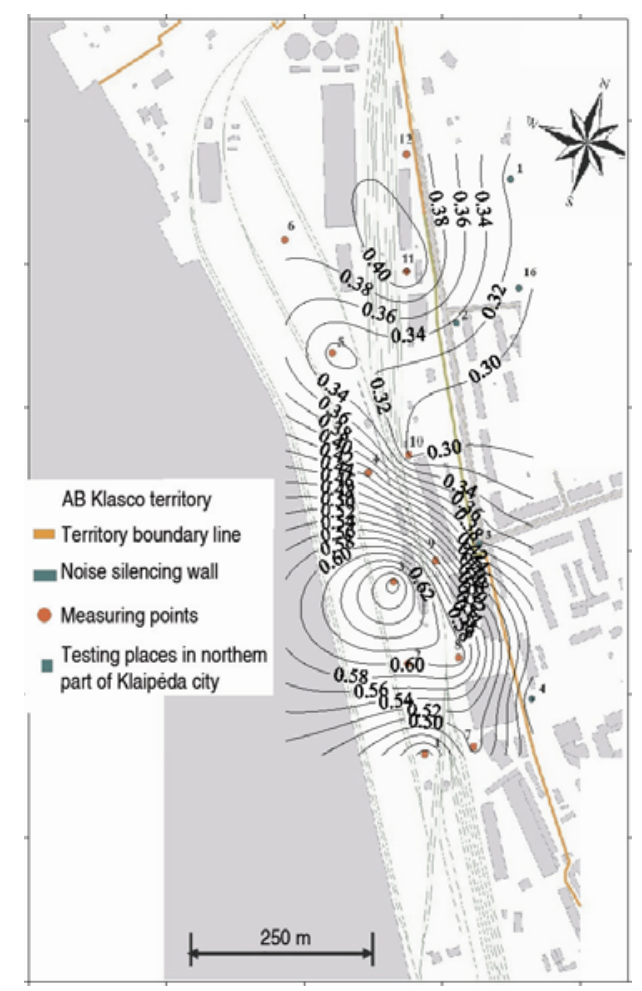

Fig 5. Dustiness in the daytime in September

In the evening on September 20 the highest concentrations spread 250 metres along the quay as well as near the warehouses. The main reasons of such concentrations are works of ferroalloy loading in the main zone of loading (points of measuring 2, 3 and 4) as well as traffic along the warehouses. (Fig 6). Concentrations in the territory of the Seaport spread evenly from $0,24 \mathrm{mg} / \mathrm{m}^{3}$ to $0,37 \mathrm{mg} / \mathrm{m}^{3}$ downwind. During measuring the wind of $1,2 \mathrm{~m} / \mathrm{s}$ was blowing, relative humidity was $79,5 \%$, air temperature was $14,2^{\circ} \mathrm{C}$. It was not detected any excess of concentrations during measuring.

In the habitable territory on Švyturys street dust concentrations increased by $0,01 \mathrm{mg} / \mathrm{m}^{3}$, and in the yards - by $0,05 \mathrm{mg} / \mathrm{m}^{3}$.

In comparison with the daytime in September, the length of the highest concentrations along the quay decreased by about 100 metres. At the Terminal of Powdery Manure Discharge concentrations decreased 1,5 time in the evening.

Comparing dust concentrations in zones I and II, it was detected that in the daytime in zone I concentrations were 1,59 time higher than in the evening, and in zone I the daytime concentrations were 1,34 time higher than those in the evening. In zone I concentrations in the daytime were 1,02 time higher than in zone II. In zone I concentrations in the evening were 1,07 time less than in zone II. 
On October18 the daytime dustiness was close to background (Fig 7). Increase of concentrations was detected at the noise silencing wall. It was influenced by the South-West wind of $1,1 \mathrm{~m} / \mathrm{s}$, relative humidity of $59,3 \%$. Concentrations in comparison with zone I increased from 0,011 to $0,14 \mathrm{mg} / \mathrm{m}^{3}$.

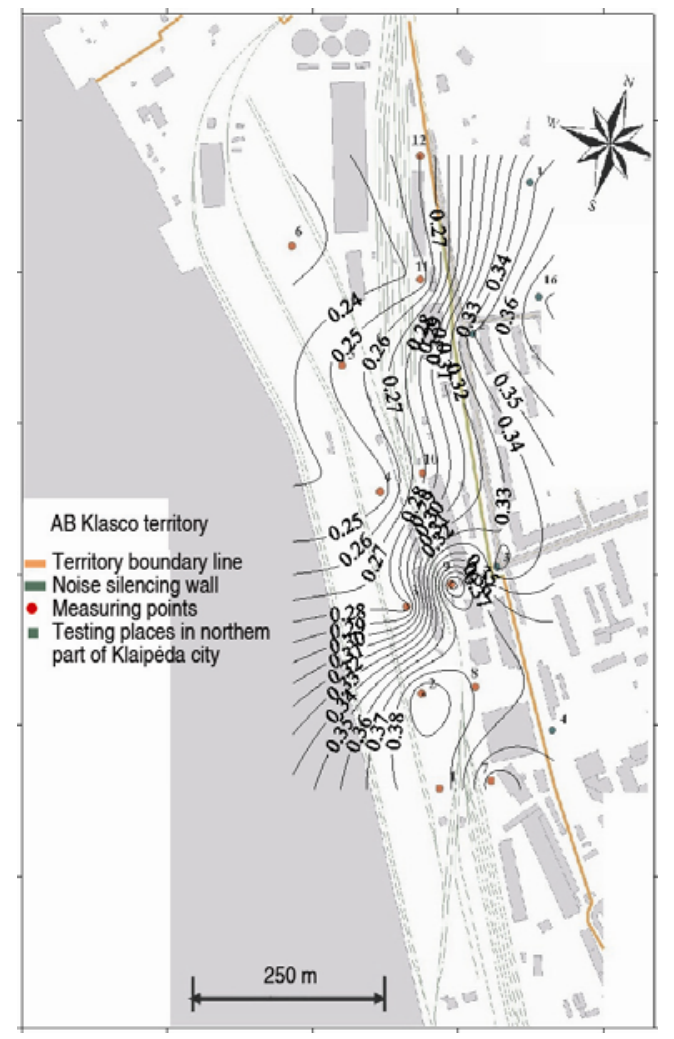

Fig 6. Dustiness in the evening in September

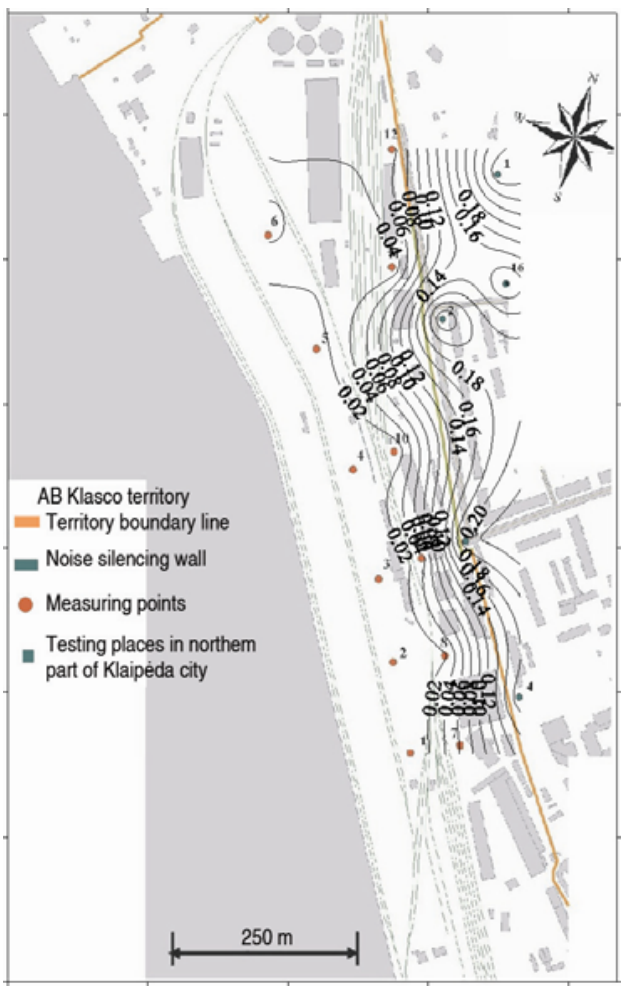

Fig 7. Dustiness in the daytime in October
Interim isolines of concentrations were distributed evenly between zone II and the noise silencing wall. Increase of concentrations at the wall was determined by the height of the wall. At measuring points 11 and 12 near the wall dust concentration was $0,08 \mathrm{mg} / \mathrm{m}^{3}$.

On Švyturys street concentrations in comparison with those, detected in the enterprise, increased by $0,02 \mathrm{mg} / \mathrm{m}^{3}$. At the nearest to the Terminal house, on Švyturys street dust concentrations increased by $0,08 \mathrm{mg} / \mathrm{m}^{3}$. In the yards on Švyturys street concentrations also increased by $0,06 \mathrm{mg} / \mathrm{m}^{3}$. A bit less increase was detected at the warehouses of ferroalloy $\left(0,02 \mathrm{mg} / \mathrm{m}^{3}\right)$.

In October and November measurements were not made in the evening due to unfavourable weather conditions.

Concentrations in the daytime detected on November 7 were also close to background (Fig 8). The highest concentrations were detected at the noise silencing wall. They were $0,08 \mathrm{mg} / \mathrm{m}^{3}$. Interim concentrations between zone II and the wall distributed gradually from $0,02 \mathrm{mg} / \mathrm{m}^{3}$ to $0,08 \mathrm{mg} / \mathrm{m}^{3}$. Only at the Terminal, where the wall is lower, concentration was $0,04 \mathrm{mg} / \mathrm{m}^{3}$.

Meanwhile, in comparison with the concentrations detected on Švyturys street they were higher by $0,02 \mathrm{mg} / \mathrm{m}^{3}$ than in the territory of the enterprise. At the nearest to the Terminal house, located on Švyturys street, dust concentrations were higher $\left(0,04 \mathrm{mg} / \mathrm{m}^{3}\right)$, and in the yards of Švyturys street concentrations were also higher $\left(0,04 \mathrm{mg} / \mathrm{m}^{3}\right)$. At the warehouses of ferroalloy dust concentrations in the yards of Švyturys street were only $0,02 \mathrm{mg} / \mathrm{m}^{3}$.

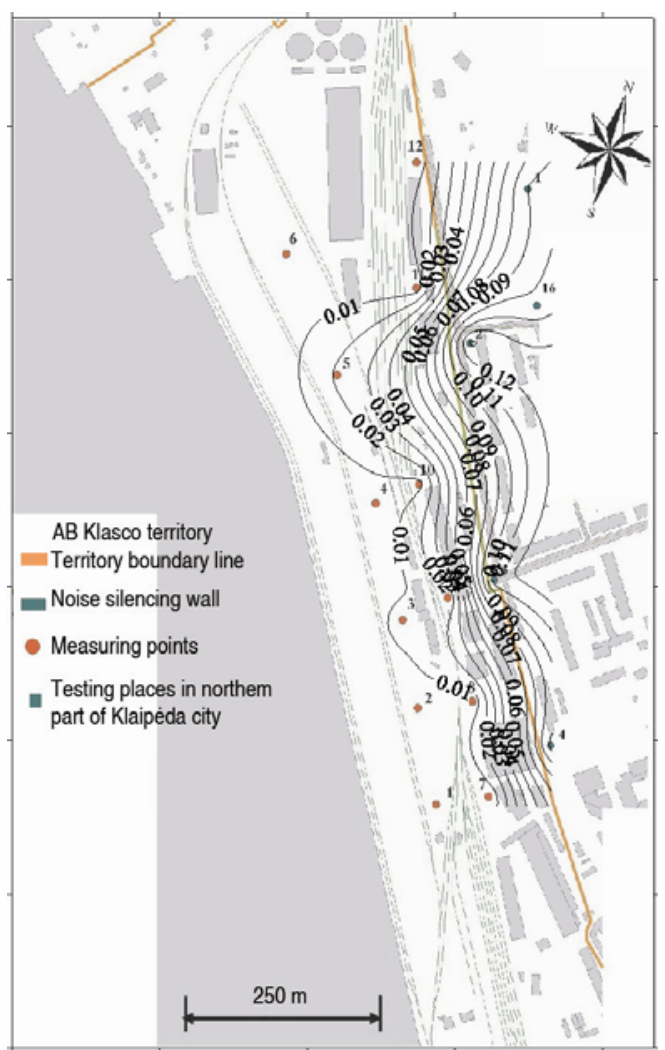

Fig 8. Dustiness in the daytime in November 
Summarizing the results, it has to be said that concentrations were mostly exceeded on the quay in the zone of the most intensive loading (measuring points 2 and 3) as well as in the zone of heavy traffic (measuring points 7, 8 and 9). Loading of ferroalloy and other powdery material as well as heavy traffic had the biggest impact on these concentrations. The highest concentrations were detected in August and September, the lowest ones - in October and November. The daytime concentrations in August were by $2 \%$ higher than in September, by 95,6\% higher than in October and by $98 \%$ higher than in November. Maximal concentration, exceeding HAC, was detected at measuring points 9, 2 and 6. HAC was exceeded, respectively, 1,89, 1,34 and 1,06 time. These concentrations were detected in the daytime in August (Fig 9).

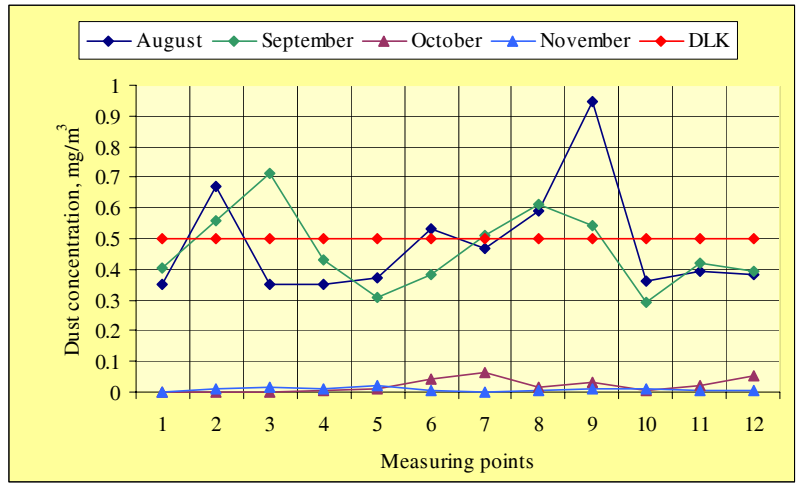

Fig 9. Distribution of air dust concentrations in the territory of the enterprise in the daytime

In August concentrations in the evening were by $2 \%$ higher than in September (Fig 10). Measurements in August and September conform with allowable norms and do not violate an allowable norm of $0,5 \mathrm{mg} / \mathrm{m}^{3}$. The highest concentrations in August were detected at measuring points 3 and 7. These concentrations were close to HAC, at point 3 concentration was $0,466 \mathrm{mg} / \mathrm{m}^{3}$, at point 7 it was $0,454 \mathrm{mg} / \mathrm{m}^{3}$. In September concentrations were similar to those in August. The highest concentrations were detected at points 2 and 9 . Their values were, respectively, $0,401 \mathrm{mg} / \mathrm{m}^{3}$ and $0,407 \mathrm{mg} / \mathrm{m}^{3}$.

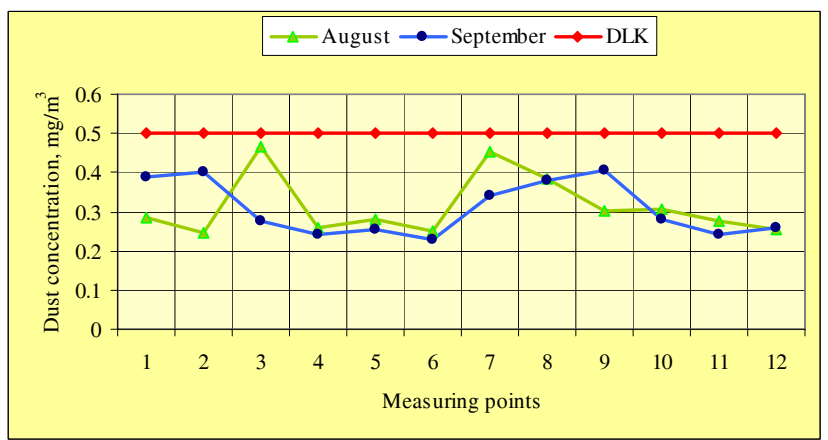

Fig 10. Distribution of air dust concentrations in the territory of the enterprise in the evening
Analysing the spread of dust into the habitable district, it was detected that in August an average value of concentrations behind the noise silencing wall in the daytime was $0,210 \mathrm{mg} / \mathrm{m}^{3}$, in the evening $-0,190 \mathrm{mg} / \mathrm{m}^{3}$ (Fig 11). In the territory of the enterprise the concentrations at the silencing wall, in comparison with measurements in the habitable district in the daytime were higher 2,5 times. Concentrations were impacted by works of loading performed in the enterprise. In the evening concentrations were 1,6 time higher in the territory of the enterprise. The difference appeared because works of loading were performed in the enterprise even if they were not very intensive. In spite of that the highest concentrations in the daytime exceeding HAC were in the territory of the enterprise at the places of loading or transportation because of heavy traffic transporting goods and intensive loadings of ferroalloy. In comparison with the noise measurements behind the noise silencing wall, in the habitable district concentrations were 5,1 times lower $\left(0,184 \mathrm{mg} / \mathrm{m}^{3}\right)$.

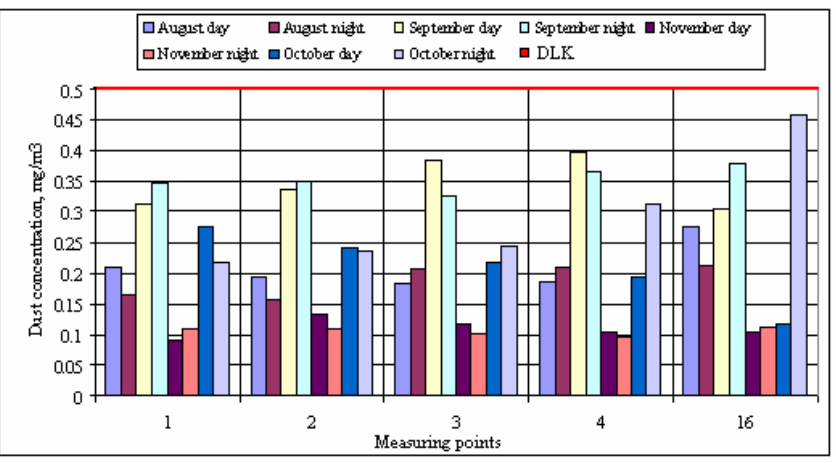

Fig 11. Data of testing dustiness in the northern part of Klaipeda city

The highest concentration, detected behind the noise silencing wall in the daytime and in the evening, was at measuring point 16 in front of the crossroad of Pušynas and Sportininkai streets, and it was, respectively, $0,276 \mathrm{mg} / \mathrm{m}^{3}$ and $0,212 \mathrm{mg} / \mathrm{m}^{3}$. Such concentrations were determined by traffic near point 16 whereas dust concentration at the nearest house (at point 2) in the daytime was $0,193 \mathrm{mg} / \mathrm{m}^{3}$, and in the evening it was $0,157 \mathrm{mg} / \mathrm{m}^{3}$. The lowest concentration in the daytime was detected at the beginning of Švyturys street in front of the warehouses of ferroalloy (at point 3), and it was $0,184 \mathrm{mg} / \mathrm{m}^{3}$. In spite of that in the territory of the enterprise in the zone of heavy traffic (at point 9), excess of HAC by 1,9 time was detected as well as at the next point $8 \mathrm{HAC}$ was exceeded 1,2 time. At point 4, 200 metres from point 3 , in front of the zone of intensive loading, concentration in the daytime was $0,187 \mathrm{mg} / \mathrm{m}^{3}$. In the zone of heavy traffic (at points 7, 8 and 9) an average concentration in the evening was $0,380 \mathrm{mg} / \mathrm{m}^{3}$, while behind the noise silencing wall concentrations were 1,8 time lower.

In September an average dust concentration in the habitable district was $0,347 \mathrm{mg} / \mathrm{m}^{3}$ in the daytime, and in the evening it was $0,354 \mathrm{mg} / \mathrm{m}^{3}$. The highest concentra- 
tions, detected at point 4 in the daytime and in front of the crossroad of Pušynas and Sportininkai streets (at point 16) in the evening, were respectively, $0,398 \mathrm{mg} / \mathrm{m}^{3}$ and $0,379 \mathrm{mg} / \mathrm{m}^{3}$. In the territory of the enterprise, in zone I, concentrations in the daytime were 1,2 time higher, and in zone II, they were 1,3 time higher than in the habitable district. In the evening in zone I they were 1,2 time lower, and in zone II, near the noise silencing wall, they were 1,1 time lower than in the habitable district. Dust concentrations in the territory of the enterprise in the daytime were the highest, while in the evening concentrations increased in the habitable district. Therefore, we may draw a conclusion that in the daytime emitted dust was carried from the territory of the enterprise to the habitable district.

In front of the main zone of loading, at point 4 , the level of dustiness in the daytime was influenced by the works of loading performed in the enterprise, whereas excess of concentrations in the enterprise was detected exactly near the points of measuring where traffic is the heaviest (at points 7, 8 and 9). An average value of concentrations at that time was $0,578 \mathrm{mg} / \mathrm{m}^{3}$, while at $200 \mathrm{~m}$ from the beginning of Švyturys street (at point 4) concentration was 1,4 time lower. Similar concentration was also detected at the beginning of Švyturys street. Concentrations differed by $3,5 \%$. In front of the crossroad of Pušynas and Sportininkai streets concentration was impacted not by dust, emitted from the enterprise, because at the crossroad of Pušynas and Švyturys streets, in front of the Terminal of Powdery Manure Disharge (at point 2), concentration of $0,35 \mathrm{mg} / \mathrm{m}^{3}$ was detected. In the evening concentrations in the habitable district at 200 metres from the beginning of Švyturys street in comparison with those in the daytime decreased by $8 \%$. In the territory of the enterprise, in the zone of heavy transport, concentration in the evening was by $1,5 \%$ lower than in the habitable district.

In October and November tests of dustiness in the territory of the enterprise were not performed in the evening because weather conditions were unfavourable.

In October dust concentration in the daytime did not exceed HAC neither in the territory of the enterprise nor in the habitable territory. An average concentration in the daytime in the habitable territory was $0,209 \mathrm{mg} / \mathrm{m}^{3}$, and in the evening it was $0,294 \mathrm{mg} / \mathrm{m}^{3}$. In comparison with the concentrations, detected in the territory of the enterprise in the daytime, concentrations in zone I were 19 times lower, in zone II they were 8 times lower than in the habitable territory. Such a difference of concentrations was determined by the fact that in the enterprise works of loading were not performed. Therefore, dust concentration in the habitable territory was not influenced by the enterprise. Similar situation emerged in the data of November. In November in zone I concentrations were 10,9 times lower, and in zone II they were 15,6 times lower than in the habitable territory. Therefore, in November dustiness in the habitable territory was also not influenced by the enterprise.

At the Terminal of Powdery Manure Discharge short-term tests were performed during which manure of potassium chloride was loaded. Therefore, at the Terminal emitted dust of potassium chloride was measured. The measured values were assessed by selected IPRV $5 \mathrm{mg} / \mathrm{m}^{3}$ in accordance with the hygiene norm $\mathrm{HN}$ 23:2001, whereas for this manure, limit norms for shortterm testing are not determined.

Upon completion of tests it was found that in zone I concentrations varied from $2,028 \mathrm{mg} / \mathrm{m}^{3}$ to $2,242 \mathrm{mg} / \mathrm{m}^{3}$ (Fig 12). The highest concentration was detected at measuring point 6. An average concentration, detected during measuring, was $2,116 \mathrm{mg} / \mathrm{m}^{3}$. For comparison of concentrations, measurements were made at a height of 1,5 metres and above wagons. Concentrations at a height of 1,5 metres were by $4,3 \%$ higher than above wagons. Concentrations above wagons were similar and differed only by $0,009 \mathrm{mg} / \mathrm{m}^{3}$.

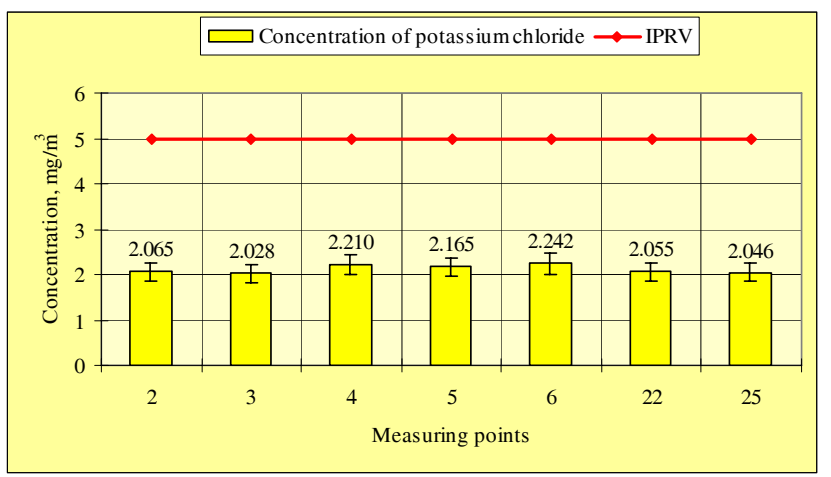

Fig 12. Distribution of dust concentrations at Terminal of Powdery Manure Dischange in zone I

In zone II the highest concentrations were detected in the direction of departure from the Terminal (Fig 13). There concentrations varied from $1,898 \mathrm{mg} / \mathrm{m}^{3}$ to $2,242 \mathrm{mg} / \mathrm{m}^{3}$. The highest concentration was detected at measuring point 20 . It was $2,242 \mathrm{mg} / \mathrm{m}^{3}$. Concentrations above wagons were rather similar; the difference between them was $0,012 \mathrm{mg} / \mathrm{m}^{3}$. An average concentration in zone II was $2,127 \mathrm{mg} / \mathrm{m}^{3}$.

In comparison with zone I, in zone II concentrations were higher by $0,5 \%$. The highest concentrations were detected at measuring points 6 and 20 which are close to each other.

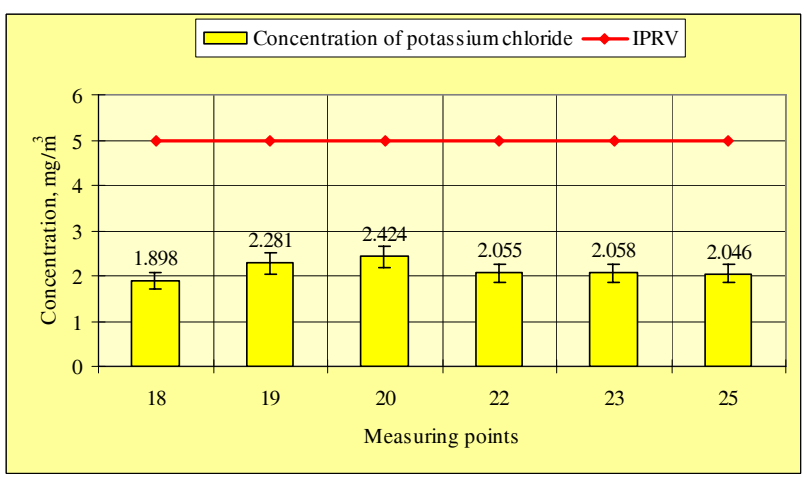

Fig 13. Distribution of dust concentrations at Terminal of Powdery Manure Discharge in zone II 
In zone III like in zone II concentrations increased in the direction of departure from the Terminal (Fig 14). The highest concentration was detected at measuring point 17 . It was $2,169 \mathrm{mg} / \mathrm{m}^{3}$. Concentrations at the entrance into the Terminal in that zone were by $21,7 \%$ lower. In zone II in front the entrance into the Terminal concentrations were lower by $15,3 \%$. An average concentration was $2,120 \mathrm{mg} / \mathrm{m}^{3}$. Above wagons the highest detected concentration was at measuring point 21 , and it was $2,334 \mathrm{mg} / \mathrm{m}^{3}$. However, in comparison with of measuring point 24 , concentration was 1,1 time higher. Difference between concentrations at a height of $1,5 \mathrm{~m}$ at measuring point 15 and above wagons at measuring point 21 was $17 \%$. They were higher above wagons. Meanwhile, comparing measuring points 17 and 24, at point 17 concentration was by $2,6 \%$ higher than at point 24. Concentration measurements above wagons were higher in the direction of entrance into the Terminal, and those at a height of $1,5 \mathrm{~m}$ were higher in the direction of departure. A similar but not very clear tendency was found in the measurements of zone II.

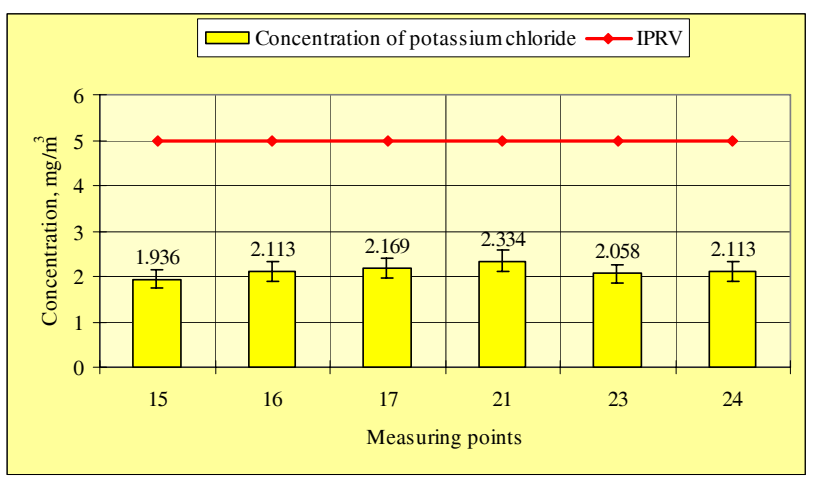

Fig 14. Distribution of dust concentrations at Terminal of Powdery Manure Discharge in zone III

In zone IV the highest concentration was detected at point 21 . It was $2,334 \mathrm{mg} / \mathrm{m}^{3}$ (Fig 15). At a height of $1,5 \mathrm{~m}$ the highest concentration was detected at point 13 . It was $1,993 \mathrm{mg} / \mathrm{m}^{3}$. Concentrations increase in the direction of departure from the Terminal. An average value of zone IV was $1,828 \mathrm{mg} / \mathrm{m}^{3}$. Concentrations at a height of $1,5 \mathrm{~m}$ were lower by $27,7 \%$ at point 9 and higher by $5,1 \%$ at point 13 .

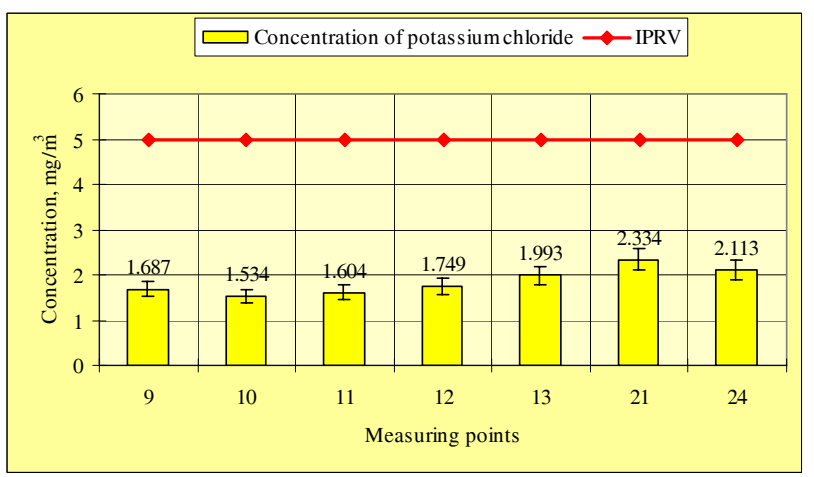

Fig 15. Distribution of dust concentrations at Terminal of Powdery Manure Disharge in zone IV
As the city background is detected according to hard particles (HAC- $0,5 \mathrm{mg} / \mathrm{m}^{3}$ ) and according to their chemical contents, they cannot be compared with the chemical contents of various kinds of powdery manure HAC of which in the air of a living environment varies from 0,1 to $2 \mathrm{mg} / \mathrm{m}^{3}$.

Concentrations in the ambient air in front of and behind the Terminal of Powdery Manure Discharge were not exceeded. The highest concentrations were detected at a distance of 50 metres from the Terminal at points 1 and 7. They were, respectively, $0,407 \mathrm{mg} / \mathrm{m}^{3}$ and $0,483 \mathrm{mg} / \mathrm{m}^{3}$. At point 8 concentrations were 4,3 times lower, while at point 14 , concentration was 1,3 time lower than at point 8 . At point 1 concentration, in comparison with point 7 , was 1,2 time lower.

\section{Conclusions}

1. The main air pollution with dust in the territory of the enterprise concentrates in the zones of heavy traffic and intensive loading. At the other measuring points air dustiness is influenced inconsiderably and usually it does not exceed limit norms except the cases of intensive loading from ships which are wharfed along the entire quay. In such cases the works of loading move on the quay in the direction of North-West. The impact of transport on air dustiness is marked. In the territory of the enterprise traffic raises dust from the pavement as well as some dust is emitted while powdery materials are transported to warehouses.

2. In August dust concentrations in the living environment in the daytime and in the evening were lower, respectively, 5,1 and 1,7 times. The highest dust concentrations were detected in front of the crossroad of Pušynas and Sportininkai streets; they were influenced by the living environment.

3. In September air dustiness was lower in the living environment than in the territory of the enterprise. Meanwhile, in the evening concentrations in the living environment increased by $11,58 \%$.

4. In October and November concentrations in the living environment were not influenced by the enterprise, because during measuring works of loading were not very intensive, the wind was weak and relative humidity was high.

5. During measurements permitted hygiene norms were not exceeded in the living environment.

6. In the working environment of the Terminal of Powdery Manure Discharge dust concentrations did not exceed the level of limit value of permitted long-term impact $\left(5 \mathrm{mg} / \mathrm{m}^{3}\right)$. Concentrations varied here from $1,534 \mathrm{mg} / \mathrm{m}^{3}$ to $2,424 \mathrm{mg} / \mathrm{m}^{3}$.

7. In the ambient air at a distance of 50 metres from the gate of the Terminal of Powdery Manure Discharge dust concentrations did not exceed a permitted norm of $0,5 \mathrm{mg} / \mathrm{m}^{3}$. Concentrations varied from $0,071 \mathrm{mg} / \mathrm{m}^{3}$ to $0,483 \mathrm{mg} / \mathrm{m}^{3}$. 


\section{References}

1. PETRAUSKAS, L.; IDZELIS, R. Klaipèdos miesto taršos kietosiomis dalelèmis analizè. Iš 8-osios Lietuvos jaunuju mokslininku konferencijos „Lietuva be mokslo - Lietuva be ateities", ivykusios $2005 \mathrm{~m}$. kovo 24 d., pranešimu medžiaga. Aplinkos apsaugos inžinerija. Vilnius: Technika, 2005, p 121-129.

2. BALTRĖNAS, P.; KAULAKYS, J. Technosferos dulkètumo kontroles metodai ir prietaisai. Vilnius: Technika, 1994. 208 p.

3. BALTRĖNAS, P.; KRASAUSKAS, M. Experimental investigation of particle concentration using mass and op- tical methods. Journal of Environmental Engineering and Landscape Management, 2005, Vol 13, No 2, p 57-64.

4. BALTRĖNAS, P.; POURU, M.; KRASAUSKAS, M. Experimental comparable investigation of particle concentration using mass, optical and vibro methods. In Environmental Engineering. 6th International Conference, May 26-27, Vilnius, Lithuania, 2005, p 12-19.

5. Kauno visuomenės sveikatos centras. Dirbančiujų sergamumas Kauno lengvosios pramonès imonèse, $2000 \mathrm{~m}$. [žiūrèta 2005-11-05]. Prieiga per internetą: [http://www.kvsc.lt/04_sveikata/c_gyv_sveikata/profesin2000.htm].

\section{ORO DULKĖTUMO IR DULKIŲ SKLAIDOS TYRIMAS JŪRŲ UOSTAMIESTYJE}

\section{P. Baltrẻnas, K.-D. Fröhner, M. Pranskevičius}

Santrauka

Aprašomi dulkètumo tyrimai, atlikti Klaipedos valstybinio jūrų uosto kompanijoje AB KLASCO. Analizuojami dulkių susidarymo šaltiniai ir pagrindinès priežastys, turejjusios ịtakos dulkių koncentracijai. Tyrimai atlikti 12 taškų, išdėstytų dviejose zonose įmonès teritorijoje. Atlikti tyrimai Biriujų trąšu krovos terminale. Jame nustatytas kalio chlorido trą̌su dulkių koncentracijos krovimo metu. Teršimo poveikiui įvertinti buvo naudoti tuo pat metu atlikti Klaipèdos šiaurinès miesto dalies duomenys. Gauti duomenys pavaizduoti Surfer 6 programa. Pagal sumodeliuotas izolinijas atlikta dulkių sklaidos analizè.

Reikšminiai žodžiai: optinis metodas, svorinis metodas, Biriujų trašų krovos terminalas, oro dulkètumas, modeliavimas.

\section{ИССЛЕДОВАНИЕ ЗАПЫЛЕННОСТИ ВОЗДУХА И РАСПРОСТРАНЕНИЕ ПЫЛИ В МОРСКОМ ПОРТУ}

\section{П. Балтренас, К.-Д. Фрёнер, М. Пранскявичюс}

Р е $з$ ю м е

Исследована запыленность воздуха в морском порту города Клайпеды (компании AO „KLASCO”). Проанализированы источники пыли, а также основные причины, обуславливающие концентрацию пыли. Исследования проведены в 12 местах морского порта, а также в терминале по разгрузке сыпучих удобрений. В нем проведены исследования концентраций хлорида калия. Выявлено влияние загрязненности пылью, использованы данные исследований северной части города Клайпеды. Полученные данные обработаны с помощью программы SURFER 6 и представлены в виде изолиний. Сделан анализ распространения пыли.

Ключевые слова: оптический метод, гравиметрический метод, терминал по разгрузке сыпучих удобрений, запыленность воздуха, распространение пыли, моделирование.

Pranas BALTRE்NAS. Dr Habil, Prof and head of Dept of Environmental Protection, Vilnius Gediminas Technical University (VGTU).

Doctor Habil of Science (air pollution), Leningrad Civil Engineering Institute (Russia), 1989. Doctor of Science (air pollution) Ivanov Textile Institute (Russia), 1975. Employment: Professor (1990), Associate Professor (1985), senior lecturer (1975), Vilnius Civil Engineering Institute (VISI, now VGTU). Publications: author of 13 monographs, 24 study-guides, over 320 research papers and 67 inventions. Honorary awards and membership: prize-winner of the Republic of Lithuania (1994), a corresponding Member of the Ukrainian Academy of Technological Cybernetics, a full Member of International Academy of Ecology and Life Protection. Probation in Germany and Finland. Research interests: air pollution, pollutant properties, pollution control equipment and methods.

Klaus-Dieter FRÖHNER. Doctor-Engineer of Science of Hamburg-Harburg Technical University, Institute of Ergonomics.

Doctorate to the qualified engineer in the University of Technology of Berlin, 1973. Main certificate in the Technological University of Berlin, 1969. Leader of the study group Production Planning and Production Control of the German Society for Operations Research, 1974-1979. Leader of Lübeck Engineer Asociation, 1979-1982. Foundation member on suggestion of the science council of the Federal Ministry of Research and Technology and Federal Ministry of Work of the Federal Republic of Germany financed committee to the investigation of the social and political change in the new federal states; coordination of the industrial safety-related research of the committee. Publications: author of 14 monographs, over 150 research papers.

Mantas PRANSKEVIČIUS. Master student, Dept of Environmental Protection, Vilnius Gediminas Technical University (VGTU). 